\title{
Damage of Splenic T Lymphocyte Proliferation and Differentiation and Its Normalization by Electroacupuncture in Morphine-Dependent Mice Mode
}

\author{
Hong-Yu Li, , 2, 3, 4 Rong Zhang, 1, 2,3,4 Cai-Lian Cui, 1, 2, 3,4 Ji-Sheng Han, 1, 2, 3, 4 \\ and Liu-Zhen $\mathrm{Wu}^{1,2,3,4}$ \\ ${ }^{1}$ Neuroscience Research Institute, Peking University, 38 Xueyuan Road, Beijing 100191, China \\ ${ }^{2}$ Department of Neurobiology, School of Basic Medical Sciences, Peking University, Beijing 100191, China \\ ${ }^{3}$ Key Lab for Neuroscience, The Ministry of Education, Beijing 100191, China \\ ${ }^{4}$ Key Lab for Neuroscience, The Ministry of Public Health, Beijing 100191, China
}

Correspondence should be addressed to Liu-Zhen Wu, clcui@bjmu.edu.cn

Received 28 January 2011; Accepted 17 March 2011

Copyright () 2011 Hong-Yu Li et al. This is an open access article distributed under the Creative Commons Attribution License, which permits unrestricted use, distribution, and reproduction in any medium, provided the original work is properly cited.

In a previous paper we reported that electroacupuncture (EA) could suppress opioid withdrawal syndrome and increase the appetite, sleep, and body weight in heroin addicts or morphine dependent animals. Considering that opioids were known to inhibit immune function, the present study was designed to observe whether EA could modulate the immune status of morphine dependent and withdrawal mice. We found that chronic morphine-induced decrease of splenic T lymphocyte proliferation and IL- 2 production can be significantly raised by $2 \mathrm{~Hz}$ EA, and the fluctuation of $\mathrm{CD} 4^{+} / \mathrm{CD} 8^{+}$ratio was also run to the baseline level by the EA. These findings indicated that chronic morphine exposure-induced immune dysfunction in mice could be normalized by $2 \mathrm{~Hz}$ EA.

\section{Introduction}

Chronic administration of opioid compounds can result in immune suppression [1,2] and increased susceptibility to virus [3, 4] and bacteria [2] in heroin addicts. Several lines of evidence showed that acupuncture had positive immune modulation effects in human and animals [5-7]. Our previous studies showed that transcutaneous acupoint nerve electrical stimulation or electroacupuncture (EA) could ameliorate the withdrawal syndrome and increase the appetite, sleep, and body weight in heroin addicts [8] or opioid-dependent animals [9]. However, it is not unclear yet whether the EA could improve the immune function or not. In the present study, we observed the changes of splenic $\mathrm{T}$ lymphocyte proliferation, IL2 production, and ratio of $\mathrm{CD}^{+}$and $\mathrm{CD}^{+} \mathrm{T}$ lymphocytes after chronic morphine treatment. We also explored whether above-mentioned changes could be reversed by EA treatment.

\section{Materials and Methods}

2.1. Animals. All experiments were performed on male $\mathrm{BALB} / \mathrm{c}$ mice from the Experimental Animal Center of the Academy of Military Medical Sciences, weighing 18-22 g at the beginning of the experiment. They were housed a single animal per cage in a $12: 12 \mathrm{~h}$ light/dark cycle with food and water available at all times. The room temperature was maintained at $24 \pm 1{ }^{\circ} \mathrm{C}$ and relative humidity at $50 \%$. Animals were conditioned and tested during the light phase of the cycle. They were handled daily during the first week after arrival. All experimental procedures were approved by the Animal Use Committee of Peking University Health Science Center.

2.2. Drugs and Reagents. Morphine hydrochloride (powder): Pharmaceutical Factory of Qinghai, China; concanavalin (Con A) and [4,5-dimethylthiazol-2-yl]-2,5-diphenyltetrazolium (MTT3) were purchased from Sigma (MO, USA); 
IL-2 ELISA kit was purchased from Endogen (Rockford, IL, USA); RPMI-1640 culture medium from GIBCO (CA, USA); anti-CD4-phicoeritrin (PE), anti-CD8-isothiocyanate fluorescein (FITC), and isotype control from BD Pharmingen (CA, USA).

2.3. Apparatus. $\mathrm{CO}_{2}$ incubator was from Sanyo (Tokyo, Japan); 550 Enzyme Labelling Instrument and 1575 Micro bore Washing Machine from BIO-RAD (CA, USA); FACSCAN from BD (NJ, USA); Han's Acupoint Nerve Stimulator, HANS LH-800, was produced by Peking University of Astronautics and Aeronautics Aviation, Beijing, China.

2.4. Morphine Dependent Mice Model. As shown in Figure 1, forty mice were divided into two groups (saline and morphine) randomly. Thirty-two of them were injected with morphine with increasing dosage, and 8 mice were treated with saline in exactly the same manner. Mice were given morphine with increasing doses from day 1 to day 10 , Morphine was dissolved in saline and each animal was injected with morphine solution $(0.1 \mathrm{~mL} / 10 \mathrm{~g}$ body weight; s.c. t.i.d, $8: 00,14: 00,20: 00)$. Eight mice were treated with saline in exactly the same manner. The morphine-treated mice were further divided into four groups. MOR: mice were treated with morphine from day 1 to day 10 , and were sacrificed $8 \mathrm{~h}$ after last treatment. MOR NW: morphine nature withdrawal group, mice received no further treatment from day 11 to day 15 , and were sacrificed on day 15 . Restraint: mice were restrained in the plastic holders without acupuncture from day 11 to day 15 , and sacrificed on day 15; MOR+EA: mice treated with morphine from day 1 to day 10 , received electroacupuncture once a day from day 11 to 15 , and then were sacrificed $2 \mathrm{~h}$ after the last electroacupuncture treatment ( $n=8$ per group).

2.5. Electroacupuncture Treatment. Mice were kept in specially designed holders, with their hind legs and tails exposed. Two stainless steel needles of $0.3 \mathrm{~mm}$ diameter were inserted into each hind leg, $(+)$ electrode placed at the acupoint ST36 ( $2 \mathrm{~mm}$ lateral to the anterior tubercle of the tibia) and (-) electrode placed at SP6 (2 $\mathrm{mm}$ proximal to the medial malleolus, at the posterior border of the tibia). Mice's both hind legs were treated in the same manner, and then connected to the output channel of an electric pulse generator. Constant current square-wave electrical stimulation produced by a programmed pulse generator (HANS LH-800) was given via the two needles. The frequency of stimulation used was $2 \mathrm{~Hz}$ $(0.6 \mathrm{~ms}$ pulse width). The intensity of the stimulation was increased stepwise from $0.7,0.8$ to $0.9 \mathrm{~mA}$, with each step lasting for $10 \mathrm{~min}$. The EA treatment was given once per day from day 11 to day 15 .

2.6. In Vitro Lymphocyte Proliferation Assay. Mouse primary T lymphocytes suspension was prepared aseptically from the spleens of the mice. A single-cell suspension of spleen cells was obtained by pushing the spleen through nylon mesh bags in D-Hank's solution. The cells were collected and washed twice with D-Hank's solution (containing 2\% FBS), centrifuged at $1000 \mathrm{rpm}$ for $10 \mathrm{~min}, 4^{\circ} \mathrm{C}$, and any remaining red blood cells were lysed by Tris- $\mathrm{NH}_{4} \mathrm{Cl}$. The cells were suspended in RPMI 1640 medium, counted under the light microscope. The cell survival rate was found to be $>90 \%$ with $0.2 \%$ trypan blue solution. The cell number was adjusted to $2 \times 10^{6} / \mathrm{mL}$, and $90 \mu \mathrm{L}$ cell suspension was transferred to each well of 96-well cell culture plate. $10 \mu \mathrm{L}$ ConA $(5 \mu \mathrm{g} / \mathrm{mL})$ or RPMI 1640 medium was transferred to the well and made the final volume to $100 \mu \mathrm{l}$. The cultures were incubated in a humidified $5 \% \mathrm{CO}_{2}$ incubator at $37^{\circ} \mathrm{C}$ for $72 \mathrm{~h}$. After incubation, $11 \mu \mathrm{L}$ MTT $(5 \mathrm{mg} / \mathrm{mL})$ was added to the each well of cell cultures and incubated for $4 \mathrm{~h}$, and then $100 \mu \mathrm{L}$ lysis buffer was added. The plates were incubated overnight at $37^{\circ} \mathrm{C}$ and the $\mathrm{OD}$ measured at $570 \mathrm{~nm}$.

2.7. Assay of Intracellular IL-2 Production. The single-cell suspension at $2 \times 10^{6} \mathrm{cell} / \mathrm{mL}$ was prepared using methods mentioned above. After being cultured with ConA $(5 \mu \mathrm{g} / \mathrm{mL})$ at $37^{\circ} \mathrm{C}$ in $5 \% \mathrm{CO}_{2}$ incubator for $48 \mathrm{~h}$, the supernatant was collected, and IL-2 content was measured with IL-2 ELISA kit according to the protocol of the manufacturer.

2.8. Splenic $\mathrm{CD}^{+}$and $\mathrm{CD}^{+} \mathrm{T}$ Lymphocytes Ratio Assay. The single-cell suspension at $1 \times 10^{7} \mathrm{cell} / \mathrm{mL}$ was prepared using the method mentioned above. The cell suspension was transferred into three tubes, $100 \mu \mathrm{L}$ per tube: one was used as blank control, one incubated with mouse monoclonal anti-isotype, and the third tube was incubated with fluorochrome-conjugated anti-CD4 (phicoeritrin-PE) and anti-CD8 (isothiocyanate fluorescein-FITC) to double immunolabelled splenic $\mathrm{CD} 8^{+}$or $\mathrm{CD} 4^{+} \mathrm{T}$ lymphocytes. The samples were incubated at $4^{\circ} \mathrm{C}$ for $40 \mathrm{~min}$, and washed twice with $0.01 \mathrm{M}$ PBS buffer. The $\mathrm{CD} 8^{+}$and $\mathrm{CD} 4^{+} \mathrm{T}$ lymphocytes were resuspended with FACS protectant solution and analyzed, using a flow cytometer equipped with an argon laser and Cell Quest software.

2.9. Statistics. The results were expressed as the mean \pm S.E. and the statistical differences between various groups were determined by one-way analysis of variance (ANOVA), followed by the Newman-Keuls posttest (Prism 4.0). $P<.05$ was considered statistically significant.

\section{Results}

3.1. Effects of $2 \mathrm{~Hz}$ Electroacupuncture on Splenic T Lymphocyte Proliferation in Morphine Dependent and Withdrawal Mice. As shown in Figure 2, splenic T lymphocyte proliferation decreased to $34.5 \%$ of that of saline group $8 \mathrm{~h}$ after last morphine injection (morphine dependent phase) $(P<.001)$, which recovered slightly 5 days after last morphine injection (morphine withdrawal phase) $(P<.05)$, but still significantly lower than the normal level $(P<.001) .12$ to $16 \mathrm{~h}$ after last morphine injection, the mice were distributed into two groups, one was merely restrained in the holder for $30 \mathrm{~min}$, serving as control for restraint stress, and the other received $2 \mathrm{~Hz}$ EA treatment $30 \mathrm{~min}$ per day for 5 consecutive days. It was shown in Figure 2 that the EA treatment accelerated the recovery of splenic $\mathrm{T}$ lymphocyte proliferation, compared with that of morphine dependent $(P<.001)$ or withdrawal 


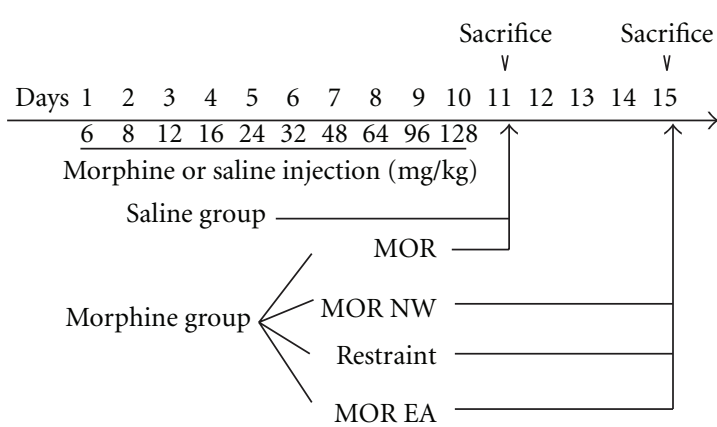

Figure 1: Experimental protocol. Forty mice were divided into two groups (saline and morphine) randomly. Thirty-two of them were injected with morphine with increasing dosage, and 8 mice were treated with saline in exactly the same manner. The morphine treated mice were further randomly divided into four groups: morphine control (MOR), morphine withdrawal (MOR NW), morphine plus restraint (Restraint), and morphine plus EA treatment $(\mathrm{MOR}+\mathrm{EA}) \cdot n=8$ per group.

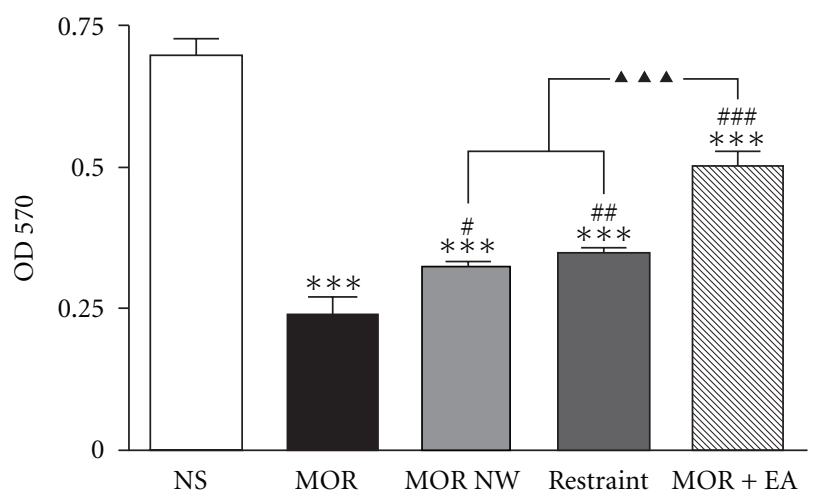

FIgURE 2: The effect of $2 \mathrm{~Hz}$ electroacupuncture on the splenic $\mathrm{T}$ lymphocyte proliferation in morphine dependent and withdrawal mice. Data were shown as means \pm S.E. and analyzed with one-way ANOVA followed by Newman-Keuls posttest. ${ }^{* * *} P<.001$ versus NS group; ${ }^{\#} P<.05,{ }^{\#} P<.01,{ }^{\# \#} P<.001$ versus MOR group; $\Delta \Delta \mathbf{\Delta} P<.001$ versus MOR NW and restraint group. $n=6-8$.

group $(P<.001)$. However, the restraint per se had no effect on lymphocyte proliferation.

\subsection{Effects of $2 \mathrm{~Hz}$ Electroacupuncture on Splenic T Lym-} phocyte IL-2 Production in Morphine Dependent and Withdrawal Mice. As shown in Figure 3, the IL-2 content in the supernatant of splenic $\mathrm{T}$ lymphocyte culture of the morphine dependent mice decreased to $17.9 \%$ of that of saline control $(P<.001)$. Five days after withdrawal the mice's IL-2 produced by splenic T lymphocyte was recovered to $33.6 \%$ of that of mice in saline group, but was still not significantly different from the morphine dependent group $(P>.05)$. After EA treatment for 5 consecutive days, the IL2 yielded by the splenic lymphocyte increased obviously and was significantly different from that of morphine dependent $(P<.001)$ and withdrawal group $(P<.01)$. Simple restraint was not effective in this regard.

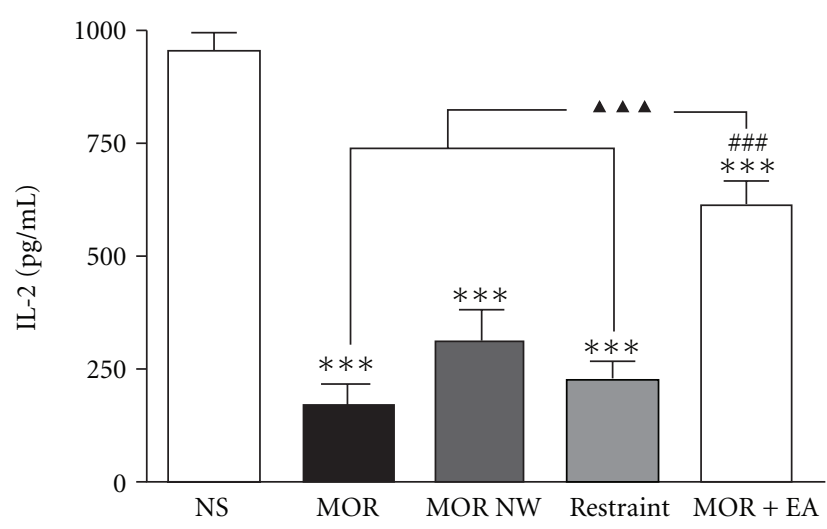

Figure 3: The effect of $2 \mathrm{~Hz}$ electroacupuncture on the Con $\mathrm{A}$ stimulated production of IL-2 in the supernatants of splenic T lymphocyte in morphine dependent and withdrawal mice. Data were shown as means \pm S.E., analyzed with one-way ANOVA followed by Newman-Keuls posttest. ${ }^{* * *} P<.001$ versus NS group; ${ }^{\#} P<.01$ versus MOR NW group; ${ }^{\Delta \boldsymbol{\Delta} \Delta} P<.001$ versus MOR and restraint group. $n=6-8$.

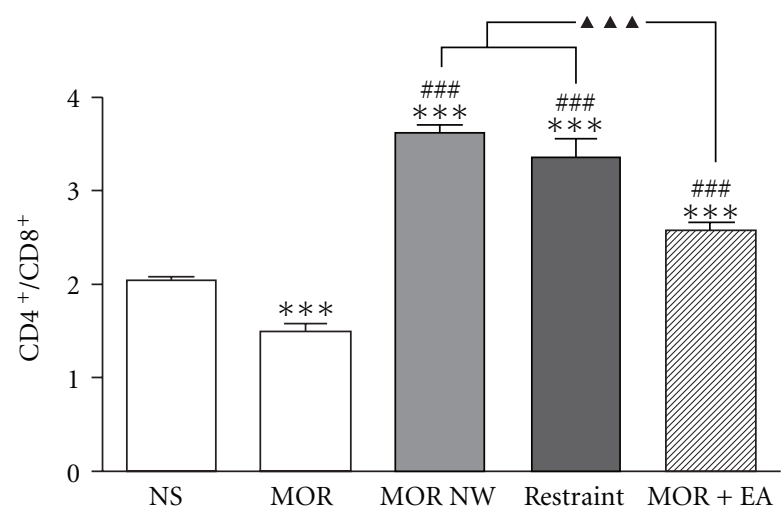

FIgURE 4: The effect of $2 \mathrm{~Hz}$ electroacupuncture on the ratio of $\mathrm{CD}^{+}$and $\mathrm{CD}^{+}$of splenic T lymphocyte in morphine dependent and withdrawal mice. Data were shown as means \pm S.E, and analyzed with one-way ANOVA followed by Newman-Keuls posttest. ${ }^{* * *} P<.001$ versus NS group; ${ }^{\# \# \#} P<.001$ versus MOR group; $\Delta \Delta \mathrm{\Delta} P<.001$ versus MOR NW and restraint group. $n=6-8$.

3.3. Effects of $2 \mathrm{~Hz}$ Electroacupuncture on the Splenic $T$ Lymphocyte CD4 $4^{+} / C D 8^{+}$Ratio in Morphine Dependent and Withdrawal Mice. As shown in Figure $4,8 \mathrm{~h}$ after the last morphine injection, the splenic $\mathrm{T}$ lymphocyte $\mathrm{CD} 4^{+} / \mathrm{CD}^{+}$ ratio decreased slightly to $72.9 \%$ of the saline group $(P<$ $.001)$. Five days after morphine withdrawal, the $\mathrm{CD} 4^{+} / \mathrm{CD}^{+}$ ratio was not only higher than the normal level, but rebounded dramatically to a level of $175 \%$ higher than the saline control $(P<.001)$. EA treatment for 5 days normalized the $\mathrm{CD}^{+} / \mathrm{CD}^{+}$ratio to a level significantly lower than the morphine natural withdrawal mice $(P<$ $.001)$, and it was higher than that of morphine dependent mice $(P<.001)$. Simple restraint was not effective in this regard. 


\section{Discussion}

It has been reported that either acute exogenous morphine [10] or opioid receptor agonists [11] treatment could suppress lymphocyte proliferation and downregulate the function of immune system in animals. The mechanisms of effect above-mentioned morphine inhibiting immune system were mainly related with $\mu$ opiate receptors in the central nervous system (caudal region of periaqueductal gray) [12] but not in the periphery (i.e., on immunocytes) $[13,14]$. On the contrary, systemic (intraperitoneal; i.p.) administration of [Met5] enkephalin with small dose $(2.5 \mathrm{mg} / \mathrm{kg})$ could increase the T lymphocyte proliferation [15], and selective $\delta$ opioid receptor antagonist, ICI-174,864 could block enhancement of $\mathrm{T}$ lymphocyte proliferation by [Met5] enkephalin analogs [16]. Therefore, consequences about the lymphocyte proliferation maybe related with the kinds of opioid receptors activated. In the present studies, chronic morphine administration for 14 days downregulated splenic lymphocyte production, which was similar with Carr's findings [17]. Carr and Carpenter reported that daily administration of morphine $(50.0 \mathrm{mg} / \mathrm{kg}$, s.c.) into alloimmunized mice (C57BL/6 into $\mathrm{C} 3 \mathrm{H} / \mathrm{HeN}$ ) for 11 days resulted in a decrease in the number of thymocytes [17].

Acupuncture has been accepted as an alternative therapy in more and more people throughout the world. It is regard as a physiological homeostasis approach in regulating immune system have been investigated in healthy volunteers, suggesting that there was a statistically significant increase in the number of $\mathrm{CD} 2^{+}, \mathrm{CD} 4^{+}, \mathrm{CD}^{+} \mathrm{CD} 11 \mathrm{~b}^{+}, \mathrm{CD} 16^{+}, \mathrm{CD} 19^{+}$, and $\mathrm{CD}^{+} 6^{+}$cells as well as IL-4, IL- $1 \beta$, and IFN- $\gamma$ levels in the cells after acupuncture stimulation of meridian points [18]. Yu et al. found that acupuncture stimulation enhanced splenic natural killer cell cytotoxicity in rats [19], which may be realized through regulating IFN-gamma production [20]. Previous studies suggested that EA stimulation on "Zusanli" (ST 36) and "Lanwei" (Extra-37) points could prevent the decrease of lymphocyte proliferative response of rats induced by intrathecal injection morphine [21]. In the present study, low frequency $(2 \mathrm{~Hz})$, low-current (0.7-0.9 mA) EA stimulations and special acupoints (ST 36 and SP 6) were selected to use. $2 \mathrm{~Hz}$ represented low frequency, which was proved beneficial for endogenous enkephalin release [22]. In morphine dependent mice model, low-current EA was safer to avoid stress than high current, so we chose $0.7-0.9 \mathrm{~mA}$ current in practice. Zu-San-Li point (ST 36) was one of the special points regulating immune function as previously reported $[23,24]$. We added San-Yin-Jiao (SP6) to constitute current circuit. All above parameters and acupoints in this study were selected seriously. It was shown that $2 \mathrm{~Hz}$ small current EA stimulation in ST 36 and SP6 reversed chronic morphine's suppressive effects on lymphocyte proliferation in mice (Figure 2 ). The result might be explained with the following mechanisms.

First, small-dose [Met5-] enkephalin could increase concanavalin A-stimulated proliferation of $\mathrm{T}$ cells in mice $[15,25]$, and our previous study has demonstrated that $2 \mathrm{~Hz}$ EA could accelerate the release of endogenous enkephalin in cerebrospinal fluid [22] and endogenous enkephalin might act on $\delta$ opioid receptor and then upregulate splenic lymphocyte proliferation.

Second, as we know, activated $\mathrm{CD} 4^{+}$lymphocyte can increase the production of IL-2, which can bind with IL2 receptors to increase lymphocyte's proliferation [26, 27]. Morphine inhibited the transcription of IL-2 in activated human T lymphocytes [28]. We found in present study that $2 \mathrm{~Hz}$ EA treatment for 5 days increased the IL-2 production (Figure 3), suggesting EA enhanced activities of $\mathrm{CD}^{+}$cells, and the latter yielded more IL-2 to accelerate lymphocyte's proliferation.

In addiction, in physiological state, $\mathrm{CD} 4^{+} / \mathrm{CD}^{+}$ratio is about 2. That is, the count of $\mathrm{CD}^{+} \mathrm{T}$ lymphocyte is about $60 \%$, and $\mathrm{CD}^{+}$lymphocyte account for $30 \%$ of total lymphocyte. Both of higher and lower ratios indicate an abnormity of immune function [29]. In this study, $\mathrm{CD}^{+} / \mathrm{CD}^{+}$ratio was downregulated in the morphinedependence phase, but rebounded dramatically in the morphine withdrawal phase (Figure 4). We speculated that after morphine-withdrawal, the suppressed immunefunction is relieved, so the $\mathrm{CD}^{+} / \mathrm{CD}^{+}$ratio rebounded. Nevertheless, $\mathrm{CD}^{+} / \mathrm{CD}^{+}$ratio inversion or unconventional increase is abnormal. After $2 \mathrm{~Hz}$ EA treatment, $\mathrm{CD} 4^{+} / \mathrm{CD}^{+}$ratio recovered to a relative normal range. Yamaguchi et al. reported that leukocyte cell counts appeared to return to appropriate levels after EA treatment in health volunteers [18]. We presumed EA played same role in morphine treated mice.

In the present study, we found that $2 \mathrm{~Hz}$ EA could improve splenic $\mathrm{T}$ lymphocyte proliferation and IL-2 production as well as a marked fluctuation of $\mathrm{CD}^{+} / \mathrm{CD}^{+}$ratio in morphine dependent and withdrawal mice. We opine that role of the low-frequency EA on immune function as follows. (1) Zu-San-Li point (ST 36) was one of special points regulating immune function as previously reported $[23,24]$. (2) The endogenous opioid peptides might be an important agent in the EA-induced immune regulation, but further investigation on the precise mechanisms of EA normalizing immune regulation in chronic morphine treated mice is requisite. In conclusion, our findings suggest that $2 \mathrm{~Hz}$ EA is a potential complementary therapy for improving immune dysfunction in opiate addicts.

\section{Acknowledgements}

Hong-Yu Li, and Rong Zhang contributed equally to this work. The authors would like to thank Dr. Albert YU ChangHai for his critical comments on the paper. The paper was supported by a Grant from the National Basic Research Program (2007CB512500) and the National Natural Science Foundation (30801491) of China.

\section{References}

[1] A. Odunayo, J. R. Dodam, M. E. Kerl, and A. E. DeClue, "Immunomodulatory effects of opioids," Journal of Veterinary Emergency and Critical Care, vol. 20, no. 4, pp. 376-385, 2010.

[2] J. Wang, R. A. Barke, J. Ma, R. Charboneau, and S. Roy, "Opiate abuse, innate immunity, and bacterial infectious diseases," Archivum Immunologiae et Therapiae Experimentalis, vol. 56, no. 5, pp. 299-309, 2008. 
[3] J. Macías, R. B. Palacios, E. Claro et al., "High prevalence of hepatitis $\mathrm{C}$ virus infection among noninjecting drug users: association with sharing the inhalation implements of crack," Liver International, vol. 28, no. 6, pp. 781-786, 2008.

[4] V. Rivera-Amill, P. S. Silverstein, R. J. Noel Jr., S. Kumar, and A. Kumar, "Morphine and rapid disease progression in nonhuman primate model of AIDS: inverse correlation between disease progression and virus evolution," Journal of Neuroimmune Pharmacology, vol. 5, no. 1, pp. 122-132, 2010.

[5] T. S. Pavão, P. Vianna, M. M. Pillat, A. B. Machado, and M. E. Bauer, "Acupuncture is effective to attenuate stress and stimulate lymphocyte proliferation in the elderly," Neuroscience Letters, vol. 484, no. 1, pp. 47-50, 2010.

[6] Y. M. Liu, X. J. Liu, S. S. Bai et al., "The effect of electroacupuncture on $\mathrm{T}$ cell responses in rats with experimental autoimmune encephalitis," Journal of Neuroimmunology, vol. 220, no. 1-2, pp. 25-33, 2010.

[7] S. K. Kim and H. Bae, "Acupuncture and immune modulation," Autonomic Neuroscience, vol. 157, no. 1-2, pp. 38-41, 2010.

[8] J. S. Han, L. Z. Wu, and C. L. Cui, "Heroin addicts treated with transcutaneous electrical nerve stimulation of identified frequencies," Regulatory Peptides, vol. 54, no. 1, pp. 115-116, 1994.

[9] L. Z. Wu, C. L. Cui, J. B. Tian, D. Ji, and J. S. Han, "Suppression of morphine withdrawal by electroacupuncture in rats: dynorphin and $\kappa$-opioid receptor implicated," Brain Research, vol. 851, no. 1-2, pp. 290-296, 1999.

[10] B. M. Bayer, S. Daussin, M. Hernandez, and L. Irvin, "Morphine inhibition of lymphocyte activity is mediated by an opioid dependent mechanism," Neuropharmacology, vol. 29, no. 4, pp. 369-374, 1990.

[11] R. D. Mellon and B. M. Bayer, "Role of central opioid receptor subtypes in morphine-induced alterations in peripheral lymphocyte activity," Brain Research, vol. 789, no. 1, pp. 56-67, 1998.

[12] D. T. Lysle, K. E. Hoffman, and L. A. Dykstra, "Evidence for the involvement of the caudal region of the periaqueductal gray in a subset of morphine-induced alterations of immune status," Journal of Pharmacology and Experimental Therapeutics, vol. 277, no. 3, pp. 1533-1540, 1996.

[13] K. Fecho, K. A. Maslonek, L. A. Dykstra, and D. T. Lysle, "Assessment of the involvement of central nervous system and peripheral opioid receptors in the immunomodulatory effects of acute morphine treatment in rats," Journal of Pharmacology and Experimental Therapeutics, vol. 276, no. 2, pp. 626-636, 1996.

[14] B. M. Bayer, M. R. Gastonguay, and M. C. Hernandez, "Distinction between the in vitro and in vivo inhibitory effects of morphine on lymphocyte proliferation based on agonist sensitivity and naltrexone reversibility," Immunopharmacology, vol. 23, no. 2, pp. 117-124, 1992.

[15] J. Gabrilovac and T. Marotti, "Gender-related differences in murine T- and B-lymphocyte proliferative ability in response to in vivo Met-enkephalin administration," European Journal of Pharmacology, vol. 392, no. 1-2, pp. 101-108, 2000.

[16] V. K. Singh, K. Bajpai, P. Narayan et al., " $\delta$-opioid receptor antagonist inhibits immunomodulation by Met-enkephalin analogs," NeuroImmunoModulation, vol. 6, no. 5, pp. 355-360, 1999.

[17] D. J. Carr and G. W. Carpenter, "Morphine-induced suppression of cytotoxic T lymphocyte activity in alloimmunized mice is not mediated through a naltrindole-sensitive delta opioid receptor," NeuroimmunoModulation, vol. 2, no. 1, pp. 44-53, 1995.
[18] N. Yamaguchi, T. Takahashi, M. Sakuma et al., "Acupuncture regulates leukocyte subpopulations in human peripheral blood," Evidence-Based Complementary and Alternative Medicine, vol. 4, no. 4, pp. 447-453, 2007.

[19] Y. Yu, T. Kasahara, T. Sato et al., "Enhancement of splenic interferon- $\gamma$, interleukin-2, and NK cytotoxicity by S36 acupoint acupuncture in F344 rats," Japanese Journal of Physiology, vol. 47, no. 2, pp. 173-178, 1997.

[20] Y. Yu, T. Kasahara, T. Sato et al., "Role of endogenous interferon- $\gamma$ on the enhancement of splenic NK cell activity by electroacupuncture stimulation in mice," Journal of Neuroimmunology, vol. 90, no. 2, pp. 176-186, 1998.

[21] T. Sun, L. N. Du, G. C. Wu, and X. D. Cao, "Effect of intrathecal morphine and electroacupuncture on cellular immune function of rats and increment of $\mu$-opioid receptor mRNA expression in PAG following intrathecal morphine," Acupuncture and Electro-Therapeutics Research, vol. 25, no. 1, pp. 1-8, 2000.

[22] J. S. Han, X. H. Chen, S. L. Sun et al., "Effect of low- and highfrequency TENS on Met-enkephalin-arg-phe and dynorphin a immunoreactivity in human lumbar CSF," Pain, vol. 47, no. 3 , pp. 295-298, 1991.

[23] G. Trinchieri, "Biology of natural killer cells," Advances in Immunology, vol. 47, pp. 187-376, 1989.

[24] M. S. Jong, S. J. Hwang, and F. P. Chen, "Effects of electro-acupuncture on serum cytokine level and peripheral blood lymphocyte subpopulation at immune-related and non-immune-related points," Acupuncture and ElectroTherapeutics Research, vol. 31, no. 1-2, pp. 45-59, 2006.

[25] J. Kowalski, "Immunologic action of Met-enkephalin fragments," European Journal of Pharmacology, vol. 347, no. 1, pp. 95-99, 1998.

[26] K. E. Hedin, M. P. Bell, K. R. Kalli, C. J. Huntoon, B. M. Sharp, and D. J. McKean, " $\delta$-opioid receptors expressed by jurkat $\mathrm{T}$ cells enhance IL- 2 secretion by increasing AP- 1 complexes and activity of the NF-AT/AP-1-binding promoter element," Journal of Immunology, vol. 159, no. 11, pp. 5431-5440, 1997.

[27] N. A. Shahabi and B. M. Sharp, "Antiproliferative effects of $\delta$ opioids on highly purified CD4+ and CD8+ murine T cells," Journal of Pharmacology and Experimental Therapeutics, vol. 273, no. 3, pp. 1105-1113, 1995.

[28] C. Börner, B. Warnick, M. Smida et al., "Mechanisms of opioid-mediated inhibition of human T cell receptor signaling," Journal of Immunology, vol. 183, no. 2, pp. 882-889, 2009.

[29] W. R. Wu, J. W. Zheng, N. Li, H. Q. Bai, K. R. Zhang, and Y. Li, "Immunosuppressive effects of dihydroetorphine, a potent narcotic analgesic, in dihydroetorphine-dependent mice," European Journal of Pharmacology, vol. 366, no. 2-3, pp. 261-269, 1999. 


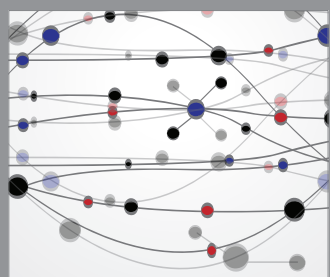

The Scientific World Journal
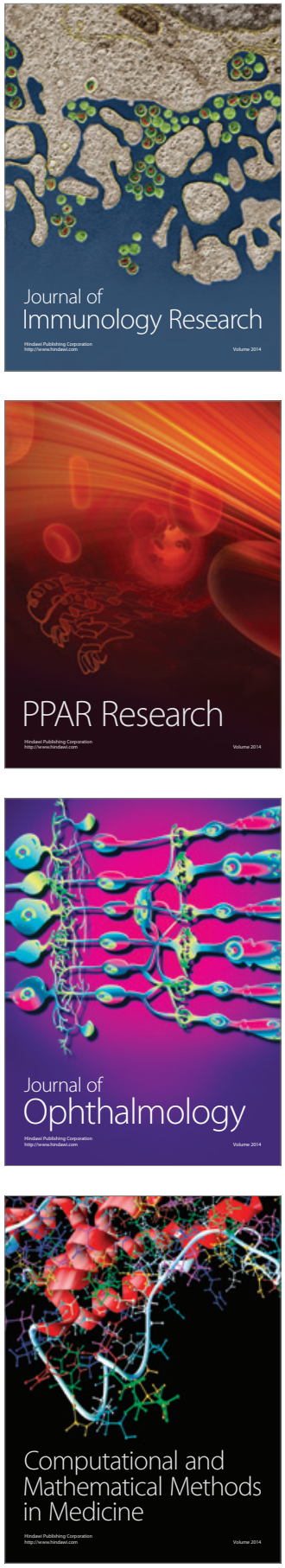

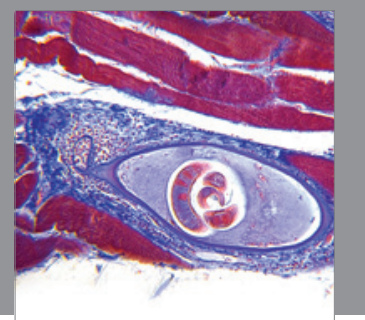

Gastroenterology

Research and Practice
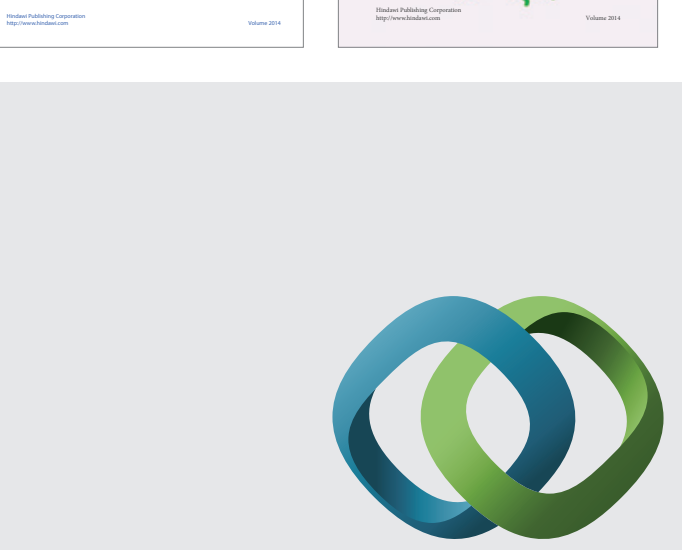

\section{Hindawi}

Submit your manuscripts at

http://www.hindawi.com
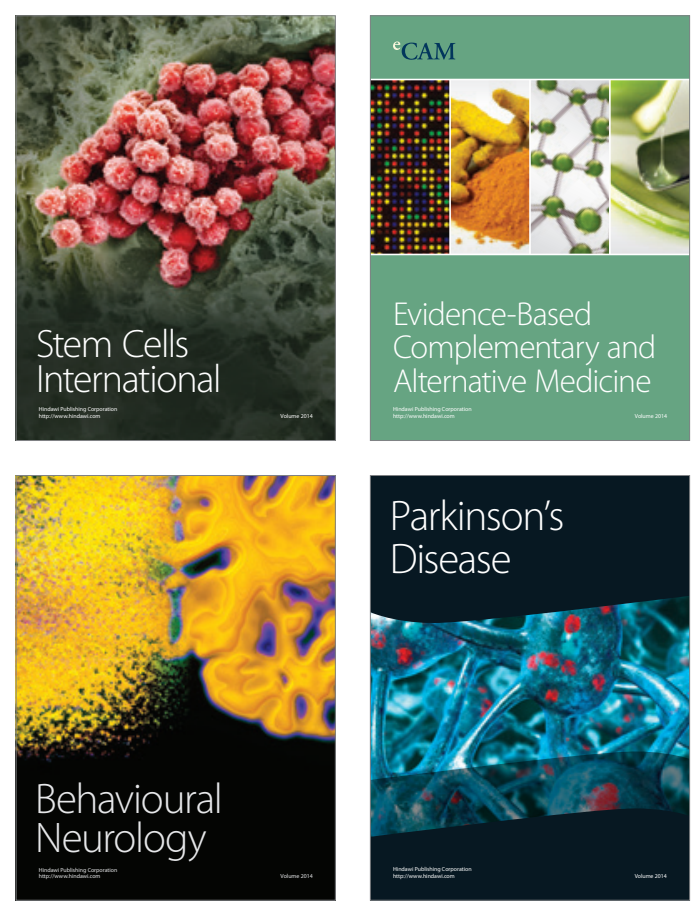

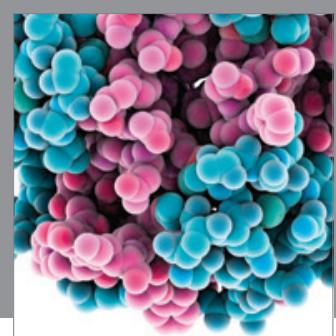

Journal of
Diabetes Research

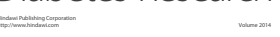

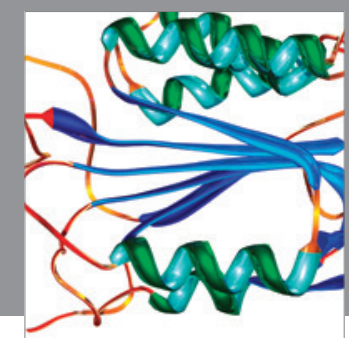

Disease Markers
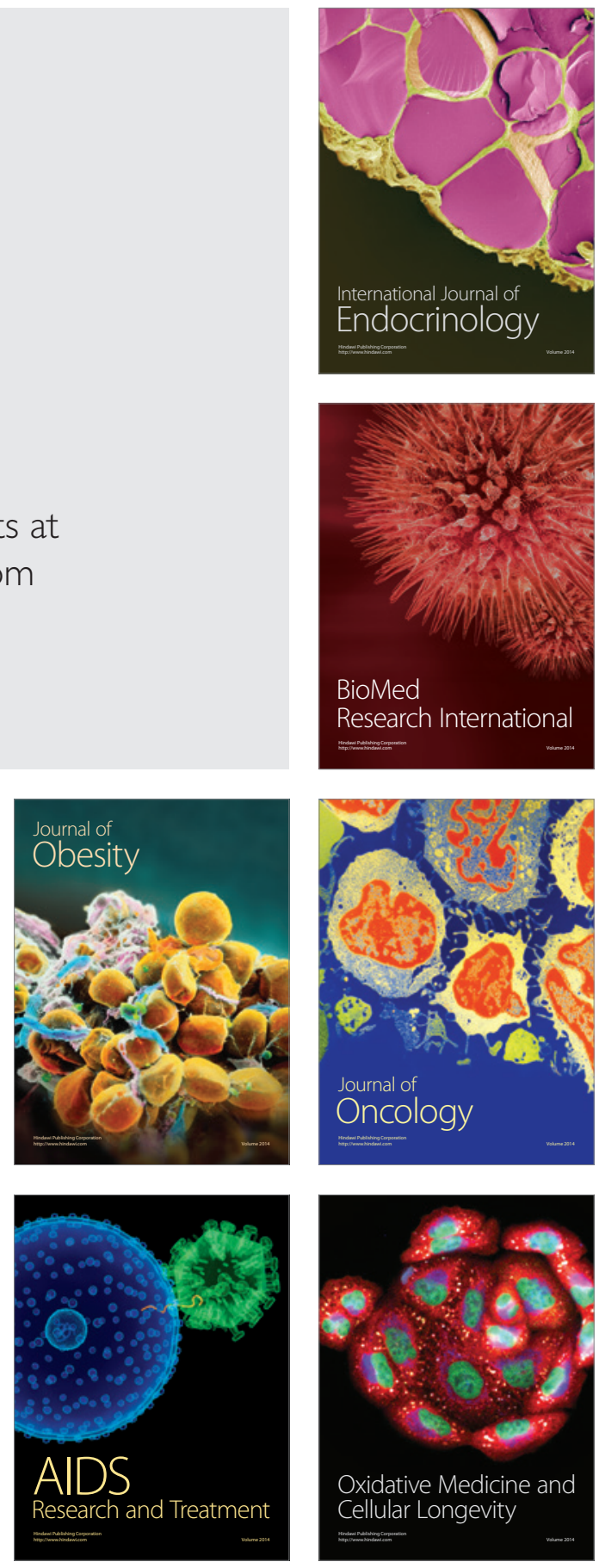